\title{
COVID-19 PANDEMIC MANAGEMENT: BEST PRACTICES AND LESSONS FROM CHINA, JAPAN AND SOUTH KOREA
}

\author{
Geetha Govindasamy ${ }^{1}$, Md Nasrudin Md Akhir ${ }^{2}$, Rohayati Paidi ${ }^{3}$
}

The management of COVID-19 pandemic is a reflection of how prepared states are when faced with a trans-boundary crisis. China, Japan and South Korea chose different strategies in containing the pandemic. All three were significantly successful in containing the pandemic in the initial stages. By using a qualitative approach, this article examines the timeline of events, measures taken during the crisis to contain the coronavirus, and the challenges faced in avoiding further spread of the virus. The importance of early detection, defined procedures, the use of digital tools and possessing enough protective medical equipment and facilities are discussed at length. Since China, Japan and the Republic of Korea have been more successful in containing the virus compared to advanced economies, this research finds that the management practices of these East Asian countries inform policy makers in the future implementation of an infectious disease response strategy.

Keywords: COVID-19 outbreak, preparedness, responses, China, Japan, South Korea

\section{INTRODUCTION}

Pandemics are never easy to deal with as they occur suddenly and at most times have no cure or preventive methods, at least in the initial stage. Experts usually define health crises as epidemic or pandemic in accordance to the severity of a disease. According to the World Health Organization (WHO), an epidemic is an illness confined to a "community or region" which exceeds "normal expectancy." 4 In contrast, a pandemic is defined more severely as one that occurs across international boundaries that affects a larger number of people. ${ }^{5}$ Though pandemics are not common but the world has seen several like the 14th century plague, the 1918 influenza outbreak and the 2019 influenza A (H1N1). On 30 January 2020, WHO's

\footnotetext{
${ }^{1}$ Corresponding Author: Senior Lecturer, Department of East Asian Studies, Faculty of Arts and Social Sciences, University of Malaya, Malaysia. Email: geethag@um.edu.my.

2 Associate Professor, Department of East Asian Studies, Faculty of Arts and Social Sciences, University of Malaya, Malaysia. Email: mnasrudi@um.edu.my.

${ }^{3}$ Senior Lecturer, Department of East Asian Studies, Faculty of Arts and Social Sciences, University of Malaya, Malaysia. Email: rohayatipaidi@um.edu.my.

4 World Health Organization (WHO), Humanitarian Health Action, no date available, available at: https://www.who.int/hac/about/definitions/en/, accessed on 12 January, 2021.

${ }_{5}^{5}$ John M. Last (ed), A Dictionary of Epidemiology, 4th edition, New York, Oxford University Press, 2001; Kelly Heath, The Classical Definition of a Pandemic is not Elusive, Bulletin of the World Health Organization, Vol 89, 2011, pp. 540-541, available at: https://www.who.int/bulletin/volumes/89/7/11088815/en/\#: : :ext=A\%20pandemic \%20is\%20defined\%20as, are\%20not\%20considered\%20pandemics, accessed on 12 January, 2021.
} 
Director-General Dr. Tedros Adhanom Ghebreyesus alerted the global public that the coronavirus 2019 (also known as COVID-19) outbreak in China has become a Public Health Emergency of International Concern (PHEIC). ${ }^{6}$ A few weeks later, on March 2020, WHO proclaimed the coronavirus outbreak a pandemic and warned that the number of people and states affected will become higher in the months to come. ${ }^{7}$ The prediction came true as most countries faced difficulties in managing and slowing down the spread of the virus or "flattening the curve."

Many countries were unable to act quickly in testing widely, tracing contacts and organizing effective coordination between local and central authorities. Much also depended on how citizens accepted or resisted countermeasures imposed by governments to curb the spread of the virus. The situation worsened rapidly within a short period of time. As reported by WHO, by 1 March 2021, globally there have been 113,820,168 confirmed cases of COVID19 , including 2,527,891 deaths. ${ }^{8}$ With various brands of vaccine available now, the management of COVID-19 has entered a new phrase. However, it is vital to understand the extent to which countries initially confronted and managed the coronavirus at a time when the disease was unknown and vaccine was unavailable to protect people from infections. This includes the strategies used by countries to delay the outbreak peak, relieve the burden on limited health infrastructure and hospitals and decreasing overall cases and health impacts. Unlike most countries that struggled to curb COVID-19 due to the disorganization between federal and local authorities, limited test kit supplies and lack of use of technological tools, China, Japan and South Korea fared much better in combating the coronavirus in its infancy.

Therefore this article examines China's, Japan's and South Korea's management strategies in curbing the spread of COVID-19, namely in the initial stages. As the coronavirus originated in China, the analysis begins with China and proceeds to Japan which succeeded early in managing the coronavirus despite being told that it was a potentially coronavirus disaster zone. This is followed by analyzing South Korea's COVID-19 strategies of contact tracing and vigorous surveillance using digital technology. Next, the article deliberates on the lessons from these three East Asian countries for future execution of mitigating health outbreaks.

\section{CHINA'S STRATEGIES IN COMBATING COVID-19}

The ongoing COVID-19 is an infectious disease which is believed to have originated in a seafood market in the city of Wuhan, Hubei province, China. On 3 January 2020, Chinese authorities informed WHO that an unknown virus was triggering viral pneumonia in Wuhan. ${ }^{9}$ By 10 January, Chinese scientists from the laboratory at the Shanghai Public Health Clinical Centre sequenced the genome of the coronavirus. ${ }^{10}$ For the first few weeks, Chinese authorities

\footnotetext{
${ }^{6}$ World Health Organization (WHO), A year Without Precedent: WHO's COVID-19 Response, 23 December, 2020, available at: https://www.who.int/news-room/spotlight/a-year-without-precedent-who-s-covid-19response, accessed on 8 January, 2021.

${ }^{7}$ Helen Branswell and Andrew Joseph, WHO Declares the Coronavirus Outbreak a Pandemic, 11 March, 2020, available at: https://www.statnews.com/2020/03/11/who-declares-the-coronavirus-outbreak-a-pandemic/, accessed on 2 January, 2021.

${ }^{8}$ World Health Organization (WHO), Coronavirus Disease (COVID-19) Dashboard, 2 March, 2021, available at: https://covid19.who.int/, accessed on 2 March 2021.

${ }^{9}$ Tom Mitchell, Sun Yu, Xinning Liu and Michael Peel, China and Covid-19: What Went Wrong in Wuhan?, Financial Times, 18 October 2020, available at: https://www.ft.com/content/82574e3d-1633-48ad-8afb71ebb3fe3dee, accessed on 8 January, 2021.

${ }^{10}$ Pinghui, Zhuang, Chinese Laboratory that First Shared Coronavirus Genome with World Ordered to Close for 'rectification', Hindering its Covid-19 Research, South China Morning Post, 28 February 2020, available at: https://www.scmp.com/news/china/society/article/3052966/chinese-laboratory-first-shared-coronavirusgenome-world-ordered, accessed on 8 January, 2021.
} 
downplayed the spread of the coronavirus and failed to underscore that there was a possibility that the disease could be transmitted between humans. ${ }^{11}$ In the first three weeks of January, Chinese officials merely reported a few dozen confirmed cases and downplayed the risks of human to human transmissions. Nevertheless, by 14 January 2020, Bangkok had already confirmed COVID-19 cases which suggested that human transmissibility has become a reality. ${ }^{12}$ It took China another 9 days before imposing a lockdown of Wuhan and nearby cities on 23 January $2020 .{ }^{13}$ Many criticized Chinese authorities for the delayed response. ${ }^{14}$ The spread of the virus globally could have been contained if the Chinese had reacted more swiftly. The source of the outbreak remains a mystery as health experts have yet to agree on how it developed. What has been accepted however is the fact that the virus spreads quickly in contained environments through droplets of saliva and mucus from the nose via coughs and sneezes. ${ }^{15}$

Table 1: Total COVID-19 cases and deaths in China

\begin{tabular}{|c|c|c|}
\hline MONTH & Total Cases & Total Deaths \\
\hline 22 Jan 2020 & 571 & 17 \\
\hline 15 Feb 2020 & 68500 & 1665 \\
\hline 14 Mar 2020 & 80844 & 3199 \\
\hline 16 April 2020 & 82367 & 3342 \\
\hline 16 May 2020 & 82941 & 4633 \\
\hline 17 June 2020 & 83265 & 4634 \\
\hline 15 July 2020 & 83611 & 4634 \\
\hline 17 Aug 2020 & 84849 & 4634 \\
\hline 16 Sept 2020 & 85214 & 4634 \\
\hline 17 Oct 2020 & 85659 & 4634 \\
\hline 17 Nov 2020 & 86361 & 4634 \\
\hline 17 Dec 2020 & 86777 & 4634 \\
\hline 17 Jan2021 & 88227 & 4635 \\
\hline 17 Feb2021 & 89795 & 4636 \\
\hline
\end{tabular}

Source: China Coronavirus, Worldometers.info, 28 February 2021

The symptoms of COVID-19 range from mild fever, loss of taste and fatigue to severe respiratory problems that could lead to death. ${ }^{16}$ Because of the transmission speed of the virus between individuals was precipitous, it was crucial for countries not to delay in responding to coronavirus. Against this backdrop, the Chinese government has defended its strategies by

11 Tom Mitchell, Sun Yu, Xinning Liu and Michael Peel, China and Covid-19: What Went Wrong in Wuhan?, Financial Times, 18 October, 2020, available at https://www.ft.com/content/82574e3d-1633-48ad-8afb71ebb3fe3dee, accessed on 8 January, 2021.

${ }^{12}$ Tom Mitchell, Sun Yu, Xinning Liu and Michael Peel, China and Covid-19: What Went Wrong in Wuhan?, Financial Times, 18 October, 2020, available at https://www.ft.com/content/82574e3d-1633-48ad-8afb71ebb3fe3dee, accessed on 8 January, 2021.

${ }^{13}$ China Study says Wuhan COVID Infections 3 Times Higher than Official Figure, Reuters, 8 January, 2021, available at: https://www.reuters.com/article/us-health-coronavirus-china-wuhan/china-study-says-wuhan-covidinfections-3-times-higher-than-official-figure-idINKBN29D0CW, accessed on 21 January, 2021.

${ }^{14}$ Tom Mitchell, Sun Yu, Xinning Liu and Michael Peel, China and Covid-19: What Went Wrong in Wuhan?, Financial Times, 18 October, 2020, available at https://www.ft.com/content/82574e3d-1633-48ad-8afb71ebb3fe3dee, accessed on 8 January, 2021.

15 Nicole Wetsman, Everything You Need to know about the Coronavirus, The Verge, 4 November, 2020, available at: ttps://www.theverge.com/2020/1/23/21078457/coronavirus-outbreak-china-wuhan-quarantine-whosars-cdc-symptoms-risk, accessed on 2 February, 2021.

${ }^{16}$ Centers for Disease Control and Prevention, United States, Symptoms of Coronavirus, 22 December, 2020 , available at: https://www.cdc.gov/coronavirus/2019-ncov/symptoms-testing/symptoms.html, accessed on 15 February, 2021. 
reasoning that the initial stage of the outbreak was ambiguous. ${ }^{17}$ As per Table 1, by March 2020, China saw 80844 confirmed cases and 3199 deaths. While that was the case, Table 1 indicates that the Chinese authorities managed to slow down the number of cases and deaths compared to the US around the same time which saw 28,405,925 cases with 511,839 deaths. Recognizing the coronavirus to be highly contagious and in the absence of a vaccine, the Chinese authorities moved quickly to stop transmission by implementing large scale preventive measures in January 2020 within Wuhan first and later to other parts of the country. Given the politically centralized system, it was quite easy for the authorities to implement countermeasures. ${ }^{18}$ Almost overnight, Wuhan, an industrial and transport center came to a near standstill. Complete lockdown came into force in the city on 23 January 2020. The lockdown lasted 76 days ending on 8 April 2020. ${ }^{19}$ Needing to implement social distancing, movement control was imposed whereby public transportation was terminated with school openings delayed. Inter and intra city travel was restricted. Only one member of each family was allowed out to purchase essential items every couple of days. ${ }^{20}$

The production of clinical gowns and surgical masks were increased and it became compulsory for everyone to wear masks. The authorities monitored the populace using drones. ${ }^{21}$ Health checkpoints were set up in various parts of the city and contact tracing became the main method to curb COVID-19. Within a few weeks, almost 9 million citizens of Wuhan were tested. To curb the infection, those with symptoms did not need have to isolate at home. Beginning of 5 February 2020, Fangcang hospitals were built swiftly. ${ }^{22}$ Fangcang hospitals located in stadiums and exhibition halls were used to isolate patients with moderate symptoms of COVID-19. In contrast, conventional hospitals were used to house patients with severe symptoms. By the second week of March, these hospitals were no longer needed. To prevent imported cases, those entering the country were also tested and quarantined. ${ }^{23}$ Despite these measures, Wuhan saw 4,635 deaths from COVID-19. ${ }^{24}$ The outbreak in Wuhan was a major factor in COVID-19 spreading to other provinces like Zhejiang, Guangdong, Henan and Hunan. In the following months, methods employed in Wuhan was replicated throughout China with immediate lockdowns and rapid mass testing. The strict methods employed eventually led to lower death toll and caseloads.

\footnotetext{
${ }^{17}$ Tom Mitchell, Sun Yu, Xinning Liu and Michael Peel, China and Covid-19: What Went Wrong in Wuhan?, Financial Times, 18 October, 2020, available at https://www.ft.com/content/82574e3d-1633-48ad-8afb71ebb3fe3dee, accessed on 8 January, 2021.

${ }_{18}$ Talha Burki, China's Successful control of COVID-19, The Lancet, Vol. 20, No. 11, 1 November, 2020, available at: https://www.thelancet.com/journals/laninf/article/PIIS1473-3099(20)30800-8/fulltext, accessed on 1 February, 2021.

${ }^{19}$ Timeline: China's COVID-19 outbreak and lockdown of Wuhan, Associated Press, 22 January, 2021, available at: https://apnews.com/article/pandemics-wuhan-china-coronavirus-pandemice6147ec0ff88affb99c811149424239d, accessed on 2 February, 2021.

${ }^{20}$ Talha Burki, China's Successful control of COVID-19, The Lancet, Vol. 20, No. 11, 1 November, 2020, available at: https://www.thelancet.com/journals/laninf/article/PIIS1473-3099(20)30800-8/fulltext, accessed on 1 February, 2021.

${ }^{21}$ Talha Burki, China's Successful control of COVID-19, The Lancet, Vol. 20, No. 11, 1 November, 2020, available at: https://www.thelancet.com/journals/laninf/article/PIIS1473-3099(20)30800-8/fulltext, accessed on 1 February, 2021.

${ }^{22}$ Fangchang Hospitals were temporary/makeshift mobile hospitals built in large spaces designed to provide basic medical care, isolate and monitor patients.

${ }^{23}$ Talha Burki, China's Successful control of COVID-19, The Lancet, Vol. 20, No. 11, 1 November, 2020, available at: $h$ ttps://www.thelancet.com/journals/laninf/article/PIIS1473-3099(20)30800-8/fulltext, accessed on 1 February, 2021.

${ }^{24}$ Emily Wang Fujiyama, Wuhan Returns to Normal as World Still Battling Pandemic, Associated Press, 23 January, 2021, available at: https://apnews.com/article/pandemics-coronavirus-pandemic-wuhan-china-asiapacific-bdd16f4306888dd33fe696fofa468e9d, accessed on 11 February, 2021.
} 
One of the major reasons why Chinese authorities were successful in slowed down the spread of COVID-19 was because the citizenry accepted measures that constrained individual freedoms. ${ }^{25}$ Compliance was all time high despite restrictive control measures. The Wuhan case justified the notion that prevention of movement of people within and outside of the city was crucial in suppressing the pandemic. As such, the Wuhan experiment has become a valuable lesson to the international community in acknowledging the need for applying strict movement controls to curb the spread of coronavirus despite limiting civil liberties.

China also provides additional lessons in implementing multiple control and preventive measures. Following is a brief account of the measures taken by China in Hangzhou, the capital of Zhejiang Province. ${ }^{26}$ It is imperative that countries have sufficient test kits from the onset in order to screen infected and non-infected people. By 13 January 2020, China had developed test kits to detect the virus. In containing and controlling COVID-19, China's risk management emphasized on the collaboration between government officials and health experts. In so doing, the citizens were well informed, the designation of infectious disease care and management facilities were planned in a practical manner and contact tracing could be done in a systematically with electronic tracking systems able to handle cases within a short time. At the same time, citizens were directed to monitor their temperature and update their profile through a health surveillance approach named "one map, one QR code, and one index." The system is used to determine how freely an individual could move around depending on one's health condition. As the first country stricken by the COVID-19 pandemic, China's response to the pandemic has shown the world that speedy response, effective communication between health experts and government, strict monitoring measures as well as community compliance are crucial elements in curtailing the spread of coronavirus.

In can be reasonably summarized that the Chinese authorities' COVID-19 management included rigorous surveillance of close contacts of infected patients, quarantining, upgrading health infrastructure and highlighting the need for self-protection through mask wearing and social distancing. These measure have assisted Chinese officials to contain the spread of the virus in the subsequent outbreaks compared to more developed countries. ${ }^{27}$ According to WHO, as of 1 March 2021, China has had 101,920 confirmed cases, with only around 4,844 deaths linked to COVID-19 transmission. In comparison, in the same time, according to WHO, the United Kingdom has had 4,176,558 confirmed cases with 122,849 deaths. ${ }^{28}$

\section{JAPAN'S STRATEGIES IN COMBATING COVID-19}

In comparison to China, Japan has had a slightly different approach in mitigating the COVID19 crisis. Being close to China geographically and having a largely aging population, Japan was at a higher risk. Outside of China, Japan became the second country after Thailand to report a COVID-19 case that originated from Wuhan. The first Japanese case was confirmed

\footnotetext{
25 Talha Burki, China's Successful control of COVID-19, The Lancet, Vol. 20, No. 11, 1 November, 2020, available at: https://www.thelancet.com/journals/laninf/article/PIIS1473-3099(20)30800-8/fulltext, accessed on 1 February, 2021.

${ }^{26}$ Xifeng Wu, Xiaolin Xu and Xuchu Wang, 6 Lessons from China's Zhejiang Province and Hangzhou on How Countries Can Prevent and Rebound from an Epidemic like COVID-19, World Economic Forum, 12 March, 2020, available at: https://www.weforum.org/agenda/2020/03/coronavirus-covid-19-hangzhou-zhejianggovernment-response/, accessed on 11 February 2021.

${ }^{27}$ Tie-Long Xu, Mei-Ying Ao, Wei-Feng Zhu, et al. China's Practice to Prevent and Control COVID-19 in the Context of Large Population Movement, Infectious Disease Poverty, Vol. 9, No. 115, 2020, available at: https://idpjournal.biomedcentral.com/articles/10.1186/s40249-020-00716-0\#citeas, accessed on 23 February, 2021.

${ }^{28}$ World Health Organization (WHO), Coronavirus Disease (COVID-19) Dashboard, 1 March, 2021, available at https://covid19.who.int/, accessed on 2 March, 2021.
} 
on 16 January 2020. A Kanagawa Prefecture resident in his 30s contracted the coronavirus during his stay in Wuhan. ${ }^{29}$ Having been exposed to pneumonia patients, the case raised the possibility of human-to-human spread at a time when very little was known about the virus. ${ }^{30}$

In the month of January, the Shinzo Abe government declared COVID-19 as a "designated infectious disease" under the Infectious Diseases Control Law as well as a "quarantinable infectious disease" under the Quarantine Act. Due to the accelerated spread of the virus around the globe, the coronavirus eventually mutated into several variants. While the first few cases in Japan came via Wuhan, others originated from Europe and the United States. ${ }^{31}$ By April 2020, the Japanese government declared a countrywide state of emergency.

Like Wuhan, Yokohama became the focal point of combatting COVID-19 in the initial stages of the pandemic in Japan. For a time, the Diamond Princess Cruise ship at the Yokohama Port had the largest concentration of COVID-19 outbreak outside of China. On one earlier segment of the trip, a 80 year old male passengers disembarked on 25 January 2020 from the Diamond Princess cruise ship in Hong Kong. Soon after, he developed a fever. By 1 February, the passenger was confirmed to be COVID-19 positive by the Hong Kong authorities. Consequently, when the Diamond Princess liner arrived at Daikoku Pier in Yokohama Port on 3 February, the ship was quarantined. Because cruise ships reflect a confined environment and the fear of infection spreading externally, quarantining of the passengers and crew members was implemented under the Quarantine Law. Public health measures like wearing masks became compulsory together with social distancing and tests were carried out on the young and old. Initially, passengers were confined to their cabins but later were allowed to go out on deck intermittently. Yet, due to the confined space, the ship became like an incubator for the coronavirus. All in all, the cruise ship which hosted 3,711 people on board underwent a 2 -week quarantine with 712 people falling sick and 13 dying from coronavirus. ${ }^{32}$ The measures adopted drew some negative responses as initially, Japanese authorities refused to allow passengers to disembark and some criticized the slowness in testing. ${ }^{33}$ Some passengers complained that there were delays in testing despite reporting symptoms and even in obtaining test results. ${ }^{34}$ Others like Dr. Amesh Adalja, from Johns Hopkins Center for Health Security in the United States observed that the quarantine violated individual rights of the passengers and poor

${ }^{29}$ Lisa Schnirring, Japan has 1st Novel Coronavirus Case; China Reports another Death, Center for Infectious Disease and Policy Nes, University of Minnesota, 16 January, 2020, available at: https://www.cidrap.umn.edu/news-perspective/2020/01/japan-has-1st-novel-coronavirus-case-china-reportsanother-death, accessed on 9 February, 2021.

${ }^{30}$ Lisa Schnirring, Japan has 1st Novel Coronavirus Case; China Reports another Death, Center for Infectious Disease and Policy Nes, University of Minnesota, 16 January, 2020, available at: https://www.cidrap.umn.edu/news-perspective/2020/01/japan-has-1st-novel-coronavirus-case-china-reportsanother-death, accessed on 9 February, 2021.

${ }^{31}$ Virus Strain in Japan Possibly Spread via Europe, U.S. since March, The Japan News, 29 April, 2020, available at: https://the-japan-news.com/news/article/0006518192, accessed on 11 December, 2020.

${ }^{32}$ Mary Van Beusekom, COVID-19 Cruise Ship Studies Reflect Unique Disease Traits, Center for Infectious Disease Research and Policy News, University of Minnesota, 15 June, 2020, available at: https://www.cidrap.umn.edu/news-perspective/2020/06/covid-19-cruise-ship-studies-reflect-unique-diseasetraits, accessed on 20 February, 2021.

${ }^{33}$ Emma Stevenson, What the Data Tells Us about Japan's Covid-19 Response, Schroders, 9 September, 2020, available at: https://www.schroders.com/en/bm/asset-management/insights/equities/what-the-data-tells-us-aboutjapans-response/, accessed on 2 February, 2021.

${ }^{34}$ Morgan McFall-Johnsen, How the 'failed' Quarantine of the Diamond Princess Cruise Ship started with 10 Coronavirus Cases and Ended with More than 700, Business Insider, 29 February, 2020, available at: https://www.businessinsider.com/how-diamond-princess-cruise-ship-coronavirus-quarantine-went-wrong-20202, accessed on 20 February, 2021. 
hygiene on the ship allowed the spread of the virus more easily. ${ }^{35}$ More damaging was the comments made by infectious-diseases expert Kentaro Iwata. According to him,

The cruise ship was completely inadequate in terms of the infection control...there was no distinction between the green zone, which is free of infection, and the red zone, which is potentially contaminated by the virus. ${ }^{36}$

In response, Japanese officials played down the criticism by indicating that most of the COVID-19 positive cases likely occurred before the quarantine period commenced on the ship. Shigeru Omi, president of the Japan Community Healthcare Organization, and a government adviser, defended by saying that "no operation is perfect." 37 Overall, the Japanese government has retained the impression that their responses to the cruise ship infections has been appropriate. A lawmaker from Abe's party aptly opined that "the Diamond Princess has proved a bit of a blind spot for us...but beyond that, there isn't a big problem for Japan with the coronavirus." 38

The 721 Diamond Princess's infected cases aside, Japan faced a growing outbreak on land as well. However, it is worth nothing that Japan did not impose countrywide lockdown as the government had limited powers to do so. Instead, the government encouraged citizens to stay at home and suspended all non-essential movements. The authorities implemented flexible workplace and public transport lockdowns. ${ }^{39}$ However, between April and May 2020, with cases rising, gradually a countrywide state of emergency was declared under the Act on Special Measures for Pandemic Influenza and New Infectious Diseases Preparedness and Response (Special Measures Act). ${ }^{40}$ Even then the emergency was mostly contingent on voluntary obedience. Japan's successful management of Covid-19 outbreak had much to do with Japanese cultural practices of cleanliness.

The containment of coronavirus was relatively easier to achieve as Japanese population was used to frequently washing hands and wearing masks. Better results were achieved because the public at large observed the 3Cs (san-mitsu) of avoiding closed spaces, crowded places as well as close contact settings. ${ }^{41}$ Although the government implemented relevant measures to curb COVID-19, Japanese citizens' compliance and conduct of respect and care for the community at large aided in the decline of the infectious disease. In other words, the citizens

\footnotetext{
${ }^{35}$ Morgan McFall-Johnsen, How the 'failed' Quarantine of the Diamond Princess Cruise Ship started with 10 Coronavirus Cases and Ended with More than 700, Business Insider, 29 February, 2020, available at: https://www.businessinsider.com/how-diamond-princess-cruise-ship-coronavirus-quarantine-went-wrong-20202, accessed on 20 February, 2021.

${ }^{36}$ Coronavirus expert: I Was So Scared on Board Diamond Princess, BBC News, 19 February, 2020, available at: https://www.bbc.com/news/av/world-asia-51564540, accessed on 2 January, 2021.

${ }^{37}$ Rocky Swift, Japan Plays Down Criticism of Coronavirus Cruise Ship Handling, Reuters, 24 February, 2020 , available at: https://www.reuters.com/article/us-china-health-japan-experts-idUSKCN20I0XW, accessed on 20 January, 2021.

${ }^{38}$ Rocky Swift, Japan Plays Down Criticism of Coronavirus Cruise Ship Handling, Reuters, 24 February, 2020, available at: https://www.reuters.com/article/us-china-health-japan-experts-idUSKCN20I0XW, accessed on 20 January, 2021.

${ }^{39}$ Emma Stevenson, What the Data Tells us About Japan's Covid-19 Response, Schroders, 9 September, 2020, available at: https://www.schroders.com/en/bm/asset-management/insights/equities/what-the-data-tells-us-aboutjapans-response/, accessed on 12 January, 2021.

${ }^{40}$ Emma Stevenson, What the Data Tells us About Japan's Covid-19 Response; Resurgence of covid-19 in Japan, 18 August, 2020, BMJ, 2020, p. 370, available at: https://www.bmj.com/content/370/bmj.m3221/rr-1, accessed on 3 February, 2021.

${ }^{41}$ Emma Stevenson, What the Data Tells us About Japan's Covid-19 Response, Schroders, 9 September, 2020, available at: https://www.schroders.com/en/bm/asset-management/insights/equities/what-the-data-tells-us-aboutjapans-response/, accessed on 12 January, 2021.
} 
were risk averse and did not want to be bear the responsibility for spreading the coronavirus. Even after the soft national lockdown and end of national emergency, citizens' continued adherence to the $3 \mathrm{Cs}$ has slowed severe infections. Table 2 underscores the trajectory of the COVID-19 confirmed cases and deaths in Japan.

Table 2: Total COVID-19 cases and deaths in Japan

\begin{tabular}{|c|c|c|}
\hline Month & Total Cases & Total Deaths \\
\hline 15 Feb 2020 & 53 & 1 \\
\hline 14 Mar 2020 & 804 & 22 \\
\hline 16 April 2020 & 9231 & 190 \\
\hline 16 May 2020 & 16237 & 725 \\
\hline 17 June 2020 & 17628 & 931 \\
\hline 15 July 2020 & 22508 & 984 \\
\hline 17 Aug 2020 & 55667 & 1099 \\
\hline 16 Sept 2020 & 76448 & 1461 \\
\hline 17 Oct 2020 & 92063 & 1661 \\
\hline 17 Nov 2020 & 119326 & 1903 \\
\hline 17 Dec 2020 & 187103 & 2739 \\
\hline 17 Jan2021 & 322296 & 4446 \\
\hline 17 Feb2021 & 419015 & 7102 \\
\hline
\end{tabular}

Source: Japan Coronavirus, Worldometers.info, 28 February 2021.

Since the virus could not be eradicated, Japanese authorities chose to instead curb the spread of infections. Interestingly enough, testing was not done as expansively as China or Russia. For instance, by July 2020, China had already tested more than 90 million people and Russia about 48 million. ${ }^{42}$ The Japanese government took into account the cost, time and labour and obtaining the risk of a false positive in conducting tests widely, especially on low-risk and asymptomatic individuals. In addition, the Japanese government opined that overwhelming hospitals with patients waiting to be tested might not be the best way to serve those with severe symptoms in need of treatment. ${ }^{43}$ Instead they concentrated on focusing on cluster infections, super-spreader events and testing those already suspected of transmission. ${ }^{44}$ Many have criticized the Japanese approach but strangely enough, despite not mass testing, Japan has been able to avoid any kind of devastating outbreak compared to other advanced industrial democracies. As of 1 March 2021, Japan has had one of the lowest death rates globally at 7,887 with 432,773 confirmed COVID-19 cases. $^{45}$ Nonetheless, with less than six months to the Tokyo Olympics and encountering another wave of infections early 2021, the government is facing renewed calls for increased mass testing from health officials and doctors. ${ }^{46}$ Japanese Health Minister Norihisa Tamura, acknowledged that,

\footnotetext{
${ }^{42}$ Ryusei Takahashi, Debate Over Japan's Virus Testing Resurfaces Amid Nationwide Outbreak, The Japan Times, 21 July, 2020, available at: https://www.japantimes.co.jp/news/2020/07/21/national/social-issues/japancoronavirus-testing-2/, accessed on 15 February, 2021.

${ }^{43}$ Suzuki Kazuto, Japan's COVID-19 Measures: Controlling the Spread without Lockdowns, Nippon.com, 10 July, 2020, available at: https://www.nippon.com/en/in-depth/d00592/, accessed on 3 February, 2021.

${ }_{44}$ Suzuki Kazuto, Japan's COVID-19 Measures: Controlling the Spread without Lockdowns, Nippon.com, 10 July, 2020, available at: https://www.nippon.com/en/in-depth/d00592/, accessed on 3 February, 2021.

45 World Health Organization (WHO), Coronavirus Disease (COVID-19) Dashboard, 1 March, 2021, available at: https://covid19.who.int/, accessed on 2 March, 2021.

${ }^{46}$ Ju-min Park, Caught Off-guard by Scant Testing, Japan Battered by COVID Winter, Reuters, 15 January, 2021, available at: https://www.reuters.com/article/us-health-coronavirus-japan-idUSKBN29K0AM, accessed on 20 February, 2021.
} 
Looking at the global trend, we need to increase the number of people receiving tests, and the demand for preventive testing is rising. ${ }^{47}$

Presently, Japanese authorities are trying to reinforce medical capacities with the help of new technologies. With months behind many other countries in terms of its vaccination program, and only conducting 55,000 perform polymerase chain reaction (PCR) tests daily, Japan is now looking into the possibility of using machines with robotic arms built by Kawasaki Heavy Industries Inc., to manage mass testing and deliver results under two hours. ${ }^{48}$ If Japan does adopt automation in coronavirus testing, there is potential for containing infections, accuracy in test results and reducing the workforce needed at testing labs. ${ }^{49}$

\section{SOUTH KOREA’S STRATEGIES IN COMBATING COVID-19}

Outside of China, South Korea was one of the countries which saw a massive outbreak of COVID-19 on its shores. The first confirmed case of COVID-19, was reported on 20 January 2020. The infected individual was a visitor from Wuhan, China who arrived at the Incheon International Airport. ${ }^{50}$ The number of confirmed cases began to rise sharply from 20 to 200 in the middle of February due to "Patient 31 " who was part of a congregation at a Shincheonji Church of Jesus the Temple of the Tabernacle of the Testimony church in Daegu. ${ }^{51}$ Like Wuhan and Yokohama, Daegu, the third largest city in South Korea became the focal point in containing the pandemic. Cases peaked on February $29^{\text {th }}$ which resulted in Daegu and Cheongdo being declared as "special management regions" and citizens were ordered not to leave their homes for at least 14 days. Gradually COVID-19 cases spread to the rest of the country. Table 3 highlights the steady increase in confirmed cases and deaths. What is notable is that the spread of the virus could be controlled due to early detection of potential cases. After experiencing a sharp growth in COVID-19 cases early in the pandemic, instead of implementing a nationwide lockdown, South Korea chose to carry out more invasive testing, tracing contacts of infected patients, isolating the sick and putting in protocols to isolate suspected individuals. Moreover, authorities implemented strong social distancing measures and encouraged citizens to avoid and minimize contacts with others.

\footnotetext{
${ }^{47}$ Japan Eyes Use of Robots to Boost COVID-19 Testing as Olympics Loom, Reuters, 19 January, 2021, available at: https://www.reuters.com/article/us-health-coronavirus-japan-testing-idUSKBN29O0SW, accessed on 20 February, 2021.

${ }^{48}$ Japan Eyes Use of Robots to Boost COVID-19 Testing as Olympics Loom, Reuters, 19 January, 2021, available at: https://www.reuters.com/article/us-health-coronavirus-japan-testing-idUSKBN29O0SW, accessed on 20 February, 2021.

${ }^{49}$ Shoya Okinaga, Coronavirus-testing Robot in Japan Takes on Key Tasks, Reducing Lab Strain, Nikkei Asia, 4 June, 2020, available at: https://asia.nikkei.com/Spotlight/Coronavirus/Coronavirus-testing-robot-in-Japan-takeson-key-tasks-reducing-lab-strain, accessed on 11 February, 2021.

${ }^{50}$ Korea Center for Disease Control and Prevention, The first imported case of the novel coronavirus (2019-nCoV) in Korea, available at: https://www.cdc.go.kr/board/board.es? $\mathrm{mid}=\mathrm{a} 30402000000 \&$ bid=0030\&act=view \&list no=365797\&tag=\&nPag $\mathrm{e}=1$, accessed on 21 January, 2020.

${ }^{51}$ David Lee and Jaehong Lee, Testing on the Move: South Korea's Rapid Response to the COVID-19 Pandemic, Transportation Research Interdisciplinary Perspectives, 21 April, 2020, available at: https://www.ncbi.nlm.nih.gov/pmc/articles/PMC7172645/, accessed on 16 February, 2021.
} 
Table 3: Total COVID-19 cases and deaths in South Korea

\begin{tabular}{|c|c|c|}
\hline MONTH & Total Cases & Total Deaths \\
\hline 15 Feb 2020 & 28 & 0 \\
\hline 14 Mar 2020 & 8086 & 72 \\
\hline 16 April 2020 & 10613 & 229 \\
\hline 16 May 2020 & 11037 & 262 \\
\hline 17 June 2020 & 12198 & 279 \\
\hline 15 July 2020 & 13551 & 289 \\
\hline 17 Aug 2020 & 15515 & 305 \\
\hline 16 Sept 2020 & 22504 & 367 \\
\hline 17 Oct 2020 & 25108 & 443 \\
\hline 17 Nov 2020 & 28998 & 494 \\
\hline 17 Dec 2020 & 46453 & 634 \\
\hline 17 Jan2021 & 72340 & 1249 \\
\hline 17 Feb2021 & 84946 & 1538 \\
\hline
\end{tabular}

Source: Korea Coronavirus, Worldometers.info, 28 February 2021.

More crucially, government officers worked together with local government officials and the national health insurance agencies to monitor travelers from abroad. ${ }^{52}$ To test the increasing number of infected individuals, local medical companies and scientific community collaborated to develop new kits by 28 February 2020 which allowed authorities to keep track of the pandemic's spread. ${ }^{53}$ For example local domestic molecular diagnostics specialists Seegene Incorporation, Kogene Biotech Company Limited, Sd Biosensor Incorporation and Solgent Company quickly developed diagnostic testing kits. ${ }^{54}$

During the early phase of the pandemic, around 600 designated testing centers were established to manage 15,000 to 20,000 tests per day. ${ }^{55}$ But by 25 March 2020, 118 institutions including KCDC, 4 National Quarantine Stations, 18 Research Institutes of Public Health and Environment (RIPHEs), and 95 private medical laboratories and hospitals had the capacity to run tests for COVID-19. ${ }^{56}$ Treatment of infected cases at the hospital placement focused on elderly patients who were at higher risk and reduced immune functions, whereas low-risk groups were encouraged to self - quarantine at home. ${ }^{57}$ At the same time, isolation strategy of confirmed cases (asymptomatic, mild, moderate, severe, and extremely severe) also included placing individuals in community facilities, and respiratory care split hospitals. The

\footnotetext{
${ }^{52}$ David Lee and Jaehong Lee, Testing on the Move: South Korea's Rapid Response to the COVID-19 Pandemic, Transportation Research Interdisciplinary Perspectives, 21 April, 2020, available at: https://www.ncbi.nlm.nih.gov/pmc/articles/PMC7172645/, accessed on 16 February, 2021.

${ }^{53}$ David Lee and Jaehong Lee, Testing on the Move: South Korea's Rapid Response to the COVID-19 Pandemic, Transportation Research Interdisciplinary Perspectives, 21 April, 2020, available at: https://www.ncbi.nlm.nih.gov/pmc/articles/PMC7172645/, accessed on 16 February, 2021.

${ }^{54}$ South Korea Approves First Four COVID-19 Test Kits under Urgent-use License, BioWorld, 17 March, 2020, available at: https://www.bioworld.com/articles/433783-south-korea-approves-first-four-covid-19-test-kitsunder-urgent-use-license, accessed on 11 February, 2021.

${ }^{55}$ Emerging COVID-19 Success Story: South Korea Learned the Lessons of MERS, Exemplars in Global Health, 30 June, 2020, available at: https://ourworldindata.org/covid-exemplar-south-korea, accessed on 19 February, 2021.

56 Amy Dighe, Lorenzo Cattarino, Steven Riley, Response to COVID-19 in South Korea and Implications for Lifting Stringent Interventions, BMC Med, Vol. 18, No. 321, available at: https://doi.org/10.1186/s12916-02001791-8, accessed on 19 February, 2021.

${ }^{57}$ Minyoung Her, Repurposing and Reshaping of Hospitals during the COVID-19 Outbreak in South Korea, One Health, Vol. 10, December 2020, 100137, available at https://www.sciencedirect.com/science/article/pii/S2352771420301002, accessed on 16 February, 2021.
} 
stratification of treatment locations overcame the issue of shortages of beds and decreased medical burden of health personnel. ${ }^{58}$

Technology became a tool in which South Korea used phones, digital maps, and databases to track and keep the public informed of the spread of coronavirus. In response to the ongoing emergency, South Koreans were more than willing to share personal data with the government. The infected person's movements were tracked through credit card use, CCTV footage and mobile phones, in order to pinpoint the infection's epicenter ${ }^{59}$ Constant alerts via text messages and the Korea Center for Disease Control \& Prevention (KCDC) website, equally contributed in early detection and tackling the spread of the coronavirus. ${ }^{60}$

It also has to be pointed out that South Korea is used to dealing with epidemics like the Severe Acute Respiratory Syndrome (SARS) and Middle East Respiratory Syndrome (MERS) outbreaks. ${ }^{61}$ Hence, the COVID-19 outbreak was easier to contain as the country had already invested heavily in infectious disease research, coordinated outbreak management led by experts and stockpiling essential goods.

In other words, strong collaborations between central government and local administrations as well as with private healthcare companies allowed for the expansion of rapid testing capacity, the dissemination of information via online news, social media, and the local government to the public directly assisted the authorities to manage the pandemic well. Compared to other advanced countries, the low number of deaths suggests that South Korea managed to control the transmission of COVID-19 very early on without restricting internal movements and access between its cities or even completely shutting down the economy. According to WHO, by 1 March 2021, South Korea had only reported 90,029 confirmed cases of COVID-19 with 1,605 deaths. ${ }^{62}$

\section{LESSONS FOR THE FUTURE}

One crucial takeaway is that countries need to put in place preventive and control strategies for health crises so as to avoid becoming the focal point of future outbreaks. The research on China, Japan and South Korea found several practical lessons that can be adopted in managing potential epidemics or pandemics. The most important lesson of all was the fact that the COVID-19 can be controlled. While Chinese, Japanese and South Korean initial approaches couldn't have been more different, these countries have done extraordinarily well in handling the coronavirus pandemic. While their COVID-19 pandemic responses may be complicated, nonetheless they highlight the need for underpinning some core competencies to incapacitate

\footnotetext{
${ }^{58}$ Minyoung Her, Repurposing and Reshaping of Hospitals during the COVID-19 Outbreak in South Korea, One Health, Vol. 10, December 2020, 100137, available at: https://www.sciencedirect.com/science/article/pii/S2352771420301002, accessed on 16 February, 2021.

${ }^{59}$ Coronavirus: Can South Korea be a Model for Virus-hit Countries?, The Economic Times, 12 March, 2020, available at: https://economictimes.indiatimes.com/news/international/world-news/coronavirus-can-south-koreabe-a-model-for-virus-hit-countries/how-has-south-korea-handled-the-epidemic/slideshow/74591881.cms, accessed on 11 February, 2021.

${ }^{60}$ Coronavirus: Can South Korea be a Model for Virus-hit Countries?, The Economic Times, 12 March, 2020, available at: https://economictimes.indiatimes.com/news/international/world-news/coronavirus-can-south-koreabe-a-model-for-virus-hit-countries/how-has-south-korea-handled-the-epidemic/slideshow/74591881.cms, accessed on 11 February, 2021.

${ }^{61}$ Emerging COVID-19 Success Story: South Korea Learned the Lessons of MERS, Exemplars in Global Health, 30 June, 2020, available at: https://ourworldindata.org/covid-exemplar-south-korea, accessed on 19 February, 2021.

${ }^{62}$ World Health Organization (WHO), Coronavirus Disease (COVID-19) Dashboard, 1 March, 2021, available at: https://covid19.who.int/, accessed on 2 March, 2021.
} 
future pandemics: maintaining efficient health governance mechanisms, using digital technology, strengthening public-private partnerships and trusting the government of the day.

Managing health crises necessitates serviceable governance mechanisms. Legal and administrative boundaries should be decided early on so that officials from the legislative and executive branches can be empowered to make quick decisions in managing any unexpected pandemics. This would enable officials to plan comprehensive range of measures without interferences. At the same time, public and private sector collaboration is also crucial, in particular moving medical services to a digital platform, producing test kits and vaccines. Sustaining long term public-private partnerships would enable governments to continually enhance their medical facilities and personnel in order to be more prepared in facing similar outbreaks.

With high transmissibility of COVID-19, authorities emphasized on containment rather than eradication of the disease. Therefore, rapid adaptation of location-based information technology became a prerequisite. By employing digital applications through migration maps, smartphones and web based tool kits, surveillance and tracing human to human transmissions could be conducted swiftly in any location without having to resort to long lockdowns which places heavy burdens on the health and economic systems. In the end, in the initial stages, digital technology was responsible in flattening COVID-19 incidence curve, in places like China, Japan and South Korea. Of course, such use of widespread technology would not have been possible without the collective compliance of the citizenry who understood the need for continual tracking of those who were infected and their contacts.

In many ways, pandemics are a test for governments to understand the extent to which their citizens really trust the governing process. As seen in China, Japan and South Korea, public health governance is centralized which meant a national epidemic response system was already in place. Additionally, East Asian populations were not supportive of the anti-vaccine or anti-science movements like some of their counterparts in the west. Usually when there is a high level of trust in government, strong and restrictive measures will be supported for public health security. To a large extent, authorities were forthright and transparent in their pandemic response. Nonetheless, civil liberties were curtailed intermittently. In some cases, the situation was so harsh that it would have been considered unacceptable in Western countries. During COVID-19, it has become normal for governments to track the movements of their citizens using sophisticated technology. Understanding the severity of the situation, citizens are prepared to sacrifice their privacy as a trade off for public health security simply because they trust their governments. Openness and frequency of the government in dispersing information on the spread of the virus encouraged citizens to voluntarily comply, especially in wearing masks and limiting social movements and activities. Data derived from monitoring applications then allowed authorities to identify infections and conduct contact tracing swiftly within a short period of time.

The experiences of China, Japan and South Korea provides the world a window into how a pandemic response strategy should be adopted. Nevertheless, it has to be noted that these countries had already invested heavily in their health care system prior to the pandemic. This is not the case in so many lesser developed countries. Moreover, the COVID-19 pandemic has devastated so many economies making it difficult for many countries to invest in their already reduced resources for the health sector. Nonetheless, the pandemic has shown that countries should consider early investments in public health as it is helps in facing sudden large scale health crises and at the same time it supports in fostering a long term sustainable healthcare system. 


\section{CONCLUSION}

This article has concentrated on the initial response strategies of China, Japan and South Korea in containing Covid-19 pandemic. Although the outbreak is still a developing situation, the quick responses and measures taken helped enormously in containing the disease subsequently. As the disease progressed globally, all three countries have succumbed to second and third waves of the pandemic. Nevertheless, with the implementation of strict containment measures including high-tech surveillance, mass testing, contact tracing, and lockdowns, these countries have had far lower rates of coronavirus infections and deaths compared to the advanced economies of Europe and America.

Now that vaccines have been developed to offer protection from COVID-19, China, Japan and South Korea face different sets of challenges. Given the challenges in efficient vaccine distribution, can current vaccines contain newer virus variants (mostly originating from the United Kingdom, South Africa and Nigeria) which appear to be more infectious than previous ones? It is understood that citizens must be vaccinated to achieve herd immunity in order to bring down infections. Achieving 60 to $70 \%$ herd community is crucial in a populous country like China. As of 1 March 2021, China has only vaccinated 3.5 percent of its population. ${ }^{63}$ There are signs in China that inoculations are slow due to the slow availability of vaccines. Thus far, the authorities there have approved vaccines produced by major firms such as Sinopharm and Sinovac. Sinopharm's chairman Yang Xiaoyun, admits that "the supply [of the vaccine] doesn't meet the demand." 64 Added to this, no vaccine is full proof. Hence, in the meantime, the question remains will the usual strategies employed prior to the development of vaccines be enough to protect citizens from newer and probably more dangerous coronaviruses.

If China has problems with its supply of vaccines, the Japanese authorities face another type of challenge. It appears that generally Japanese have a distrust of vaccines due to past health issues related to vaccines for polio, HPV and MMR. Hence, Japan is the last major economy to begin the vaccination program. Using the Pfizer-BioNTech vaccine, inoculations only started in the middle of January 2021. Although vaccination is not compulsory in Japan, authorities are trying to mass vaccinate before the start of the Tokyo Summer Olympic Games. South Korea began its vaccination program using vaccines made by AstraZeneca, late February 2021. Unlike China or Japan, at the time of writing, it has been reported that the South Korean government will buy more vaccines than required for its 52 million population as it intends to reach herd immunity as fast as possible.

The reality is that communities in any given country are less likely to get COVID-19 only when herd immunity is reached. By the looks of it, the production and the delivery of the vaccines together with the administration of vaccination programs may take some time. Against this backdrop, COVID-19 is here to stay for another couple of months at least. It is not too late for countries who are still struggling to contain COVID-19 to learn and adapt the innovative responses employed by China, Japan or South Korea who have proven relatively quick results in flattening the curve on COVID-19.

\footnotetext{
${ }^{63}$ Coronavirus: China Aims to Vaccinate $40 \%$ of its Population before June Ends, The Straits Times, 1 March 2021, available at: https://www.straitstimes.com/asia/east-asia/coronavirus-china-aims-to-vaccinate-40-of-itspopulation-before-june-ends, accessed on 2 March, 2021.

64 Emily Feng, China's Vaccine Campaign Hits A Few Bumps, NPR, 3 February, 2021, available at: https://www.npr.org/sections/goatsandsoda/2021/02/03/963264535/chinas-vaccine-campaign-hits-a-few-bumps, accessed on 1 February, 2021.
} 


\section{REFERENCES}

Amy Dighe, Lorenzo Cattarino, Steven Riley, Response to COVID-19 in South Korea and Implications for Lifting Stringent Interventions, BMC Med, Vol. 18, No. 321, available at: https://doi.org/10.1186/s12916-020-01791-8, accessed on 19 February, 2021.

Centers for Disease Control and Prevention, United States, Symptoms of Coronavirus, 22 December, 2020, available at: https://www.cdc.gov/coronavirus/2019-ncov/symptomstesting/symptoms.html, accessed on 15 February, 2021.

China Study says Wuhan COVID Infections 3 Times Higher than Official Figure, Reuters, 8 January, 2021, available at: https://www.reuters.com/article/us-health-coronavirus-chinawuhan/china-study-says-wuhan-covid-infections-3-times-higher-than-official-figureidINKBN29D0CW, accessed on 21 January, 2021.

Coronavirus expert: I Was So Scared on Board Diamond Princess, BBC News, 19 February, 2020, available at: https://www.bbc.com/news/av/world-asia-51564540, accessed on 2 January, 2021.

Coronavirus: Can South Korea be a Model for Virus-hit Countries?, The Economic Times, 12 March, 2020, available at: https://economictimes.indiatimes.com/news/international/worldnews/coronavirus-can-south-korea-be-a-model-for-virus-hit-countries/how-has-south-koreahandled-the-epidemic/slideshow/74591881.cms, accessed on 11 February, 2021.

Coronavirus: China Aims to Vaccinate $40 \%$ of its Population before June Ends, The Straits Times, 1 March 2021, available at: https://www.straitstimes.com/asia/east-asia/coronaviruschina-aims-to-vaccinate-40-of-its-population-before-june-ends, accessed on 2 March, 2021.

David Lee and Jaehong Lee, Testing on the Move: South Korea's Rapid Response to the COVID-19 Pandemic, Transportation Research Interdisciplinary Perspectives, 21 April, 2020, available at: https://www.ncbi.nlm.nih.gov/pmc/articles/PMC7172645/, accessed on 16 February, 2021.

Emerging COVID-19 Success Story: South Korea Learned the Lessons of MERS, Exemplars in Global Health, 30 June, 2020, available at: https://ourworldindata.org/covid-exemplarsouth-korea, accessed on 19 February, 2021.

Emily Feng, China's Vaccine Campaign Hits A Few Bumps, NPR, 3 February, 2021, available at: $\quad$ https://www.npr.org/sections/goatsandsoda/2021/02/03/963264535/chinas-vaccinecampaign-hits-a-few-bumps, accessed on 1 February, 2021.

Emily Wang Fujiyama, Wuhan Returns to Normal as World Still Battling Pandemic, Associated Press, 23 January, 2021, available at: https://apnews.com/article/pandemicscoronavirus-pandemic-wuhan-china-asia-pacific-bdd16f4306888dd33fe696f0fa468e9d, accessed on 11 February, 2021.

Emma Stevenson, What the Data Tells Us about Japan's Covid-19 Response, Schroders, 9 September, 2020, available at: https://www.schroders.com/en/bm/assetmanagement/insights/equities/what-the-data-tells-us-about-japans-response/, accessed on 2 February, 2021. 
Helen Branswell and Andrew Joseph, WHO Declares the Coronavirus Outbreak a Pandemic, 11 March, 2020, available at: https://www.statnews.com/2020/03/11/who-declares-thecoronavirus-outbreak-a-pandemicl, accessed on 2 January, 2021.

Japan Eyes Use of Robots to Boost COVID-19 Testing as Olympics Loom, Reuters, 19 January, 2021, available at: https://www.reuters.com/article/us-health-coronavirus-japantesting-idUSKBN2900SW, accessed on 20 February, 2021.

John M. Last (Ed), A Dictionary of Epidemiology, 4th edition, New York, Oxford University Press, 2001.

Ju-min Park, Caught Off-guard by Scant Testing, Japan Battered by COVID Winter, Reuters, 15 January, 2021, available at: https://www.reuters.com/article/us-health-coronavirus-japanidUSKBN29K0AM, accessed on 20 February, 2021.

Kelly Heath, The Classical Definition of a Pandemic is not Elusive, Bulletin of the World Health Organization, Vol 89, 2011, pp. 540-541, available at: https://www.who.int/bulletin/volumes/89/7/11-

088815/en/\#: :text=A\%20pandemic\%20is\%20defined\%20as, are\%20not\%20considered\%20 pandemics, accessed on 12 January, 2021.

Korea Center for Disease Control and Prevention, The first imported case of the novel coronavirus $(2019-\mathrm{nCoV})$ in https://www.cdc.go.kr/board/board.es? mid=a30402000000\&bid=0030\&act=view\&list_no=3 $65797 \& \operatorname{tag}=\& n$ Page $=1$, accessed on 21 January, 2020.

Lisa Schnirring, Japan has 1st Novel Coronavirus Case; China Reports another Death, Center for Infectious Disease and Policy Nes, University of Minnesota, 16 January, 2020, available at: https://www.cidrap.umn.edu/news-perspective/2020/01/japan-has-1st-novel-coronaviruscase-china-reports-another-death, accessed on 9 February, 2021.

Mary Van Beusekom, COVID-19 Cruise Ship Studies Reflect Unique Disease Traits, Center for Infectious Disease Research and Policy News, University of Minnesota, 15 June, 2020, available at: https://www.cidrap.umn.edu/news-perspective/2020/06/covid-19-cruise-shipstudies-reflect-unique-disease-traits, accessed on 20 February, 2021.

Minyoung Her, Repurposing and Reshaping of Hospitals during the COVID-19 Outbreak in South Korea, One Health, Vol. 10, December 2020, 100137, available at https://www.sciencedirect.com/science/article/pii/S2352771420301002, accessed on 16 February, 2021.

Morgan McFall-Johnsen, How the 'failed' Quarantine of the Diamond Princess Cruise Ship started with 10 Coronavirus Cases and Ended with More than 700, Business Insider, 29 February, 2020, available at: https://www.businessinsider.com/how-diamond-princess-cruiseship-coronavirus-quarantine-went-wrong-2020-2, accessed on 20 February, 2021.

Nicole Wetsman, Everything You Need to know about the Coronavirus, The Verge, 4 November, 2020, available at: ttps://www.theverge.com/2020/1/23/21078457/coronavirus- 
outbreak-china-wuhan-quarantine-who-sars-cdc-symptoms-risk, accessed on 2 February, 2021.

Pinghui, Zhuang, Chinese Laboratory that First Shared Coronavirus Genome with World Ordered to Close for 'rectification', Hindering its Covid-19 Research, South China Morning Post, 28 February 2020, available at: https://www.scmp.com/news/china/society/article/3052966/chinese-laboratory-first-sharedcoronavirus-genome-world-ordered, accessed on 8 January, 2021.

Rocky Swift, Japan Plays Down Criticism of Coronavirus Cruise Ship Handling, Reuters, 24 February, 2020, available at: https://www.reuters.com/article/us-china-health-japan-expertsidUSKCN20I0XW, accessed on 20 January, 2021.

Ryusei Takahashi, Debate Over Japan's Virus Testing Resurfaces Amid Nationwide Outbreak, The Japan Times, 21 July, 2020, available at: https://www.japantimes.co.jp/news/2020/07/21/national/social-issues/japan-coronavirustesting-2/, accessed on 15 February, 2021.

Shoya Okinaga, Coronavirus-testing Robot in Japan Takes on Key Tasks, Reducing Lab Strain, Nikkei Asia, 4 June, 2020, available at: https://asia.nikkei.com/Spotlight/Coronavirus/Coronavirus-testing-robot-in-Japan-takes-onkey-tasks-reducing-lab-strain, accessed on 11 February, 2021.

South Korea Approves First Four COVID-19 Test Kits under Urgent-use License, BioWorld, 17 March, 2020, available at: https://www.bioworld.com/articles/433783-south-koreaapproves-first-four-covid-19-test-kits-under-urgent-use-license, accessed on 11 February, 2021.

Suzuki Kazuto, Japan's COVID-19 Measures: Controlling the Spread without Lockdowns, Nippon.com, 10 July, 2020, available at: https://www.nippon.com/en/in-depth/d00592/, accessed on 3 February, 2021.

Talha Burki, China's Successful control of COVID-19, The Lancet, Vol. 20, No. 11, 1 November, 2020, available at: https://www.thelancet.com/journals/laninf/article/PIIS14733099(20)30800-8/fulltext, accessed on 1 February, 2021.

Timeline: China's COVID-19 outbreak and lockdown of Wuhan, Associated Press, 22 January, 2021, available at: https://apnews.com/article/pandemics-wuhan-china-coronavirus-pandemice6147ec0ff88affb99c811149424239d, accessed on 2 February, 2021.

Tom Mitchell, Sun Yu, Xinning Liu and Michael Peel, China and Covid-19: What Went Wrong in Wuhan?, Financial Times, 18 October 2020, available at: https://www.ft.com/content/82574e3d-1633-48ad-8afb-71ebb3fe3dee, accessed on 8 January, 2021.

Virus Strain in Japan Possibly Spread via Europe, U.S. since March, The Japan News, 29 April, 2020, available at: https://the-japan-news.com/news/article/0006518192, accessed on 11 December, 2020. 
World Health Organization (WHO), A year Without Precedent: WHO's COVID-19 Response, 23 December, 2020, available at: https://www.who.int/news-room/spotlight/a-year-withoutprecedent-who-s-covid-19-response, accessed on 8 January, 2021.

World Health Organization (WHO), Coronavirus Disease (COVID-19) Dashboard, 2 March, 2021, available at: https://covid19.who.int/, accessed on 2 March 2021.

World Health Organization (WHO), Humanitarian Health Action, no date available, available at: https://www.who.int/hac/about/definitions/en/, accessed on 12 January, 2021.

Xifeng Wu, Xiaolin Xu and Xuchu Wang, 6 Lessons from China's Zhejiang Province and Hangzhou on How Countries Can Prevent and Rebound from an Epidemic like COVID-19, World Economic Forum, 12 March, 2020, available at: https://www.weforum.org/agenda/2020/03/coronavirus-covid-19-hangzhou-zhejianggovernment-response/, accessed on 11 February 2021. 